\title{
Resenha
}

Laço social e educação: um estudo sobre os efeitos do encontro com o outro no contexto escolar

Mônica Maria Farid Rahme Belo Horizonte: Fino Traço, 2014, 428p.

\section{A AVENTURA DO OUTRO NO CONTEXTO ESCOLAR}

\author{
Margareth Diniz
}

DOI: http://dx.doi.org/10.11606/issn.1981-1624.v19i3p519-522

A temática central do livro Laço social e educação é o processo de escolarização de alunos com necessidades educacionais especiais na escola comum e, mais especificamente, os efeitos que a convivência, nesse contexto, pode produzir para os sujeitos. Para tanto, a autora parte de quatro perguntas centrais: a proposta da Educação Inclusiva de superar a segregação escolar historicamente imposta às crianças com deficiência tem se tornado possível nas relações que se estabelecem na escola?; Como as crianças constituem e vivenciam seus laços no espaço escolar?; O que elas produzem discursivamente sobre essa experiência?; $\mathrm{O}$ que esse fato coloca para pensarmos na relação laço social, discurso e subjetividade?

Entendendo que essas questões tangenciam um plano macro, ligado às discussões políticas e acadêmicas sobre o tema da educação especializada e da inclusão escolar, e em um plano micro, relacionado ao que se pode passar na experiência escolar, a autora organiza seu trabalho a partir de três eixos específicos. No primeiro, discute o conceito de laço social a partir do referencial psicanalítico, o que permite um frutífero diálogo, no primeiro capítulo, com produções de Freud e Lacan sobre o tema, que permitem explorar 
sua particularidade no campo da psicanálise, bem como seus impasses atuais e sua interface com a questão educacional. No segundo eixo, subdivido em dois capítulos, a autora realiza uma retomada histórica do processo de constituição da Educação Especial, a partir de meados do Século XVIII, e evidencia o percurso que permitiu a emergência de saberes e práticas relacionadas à educação das pessoas ditas com deficiência até procedimentos mais recentes, como o mainstreaming, a integração e a proposta de uma educação inclusiva. $\mathrm{Na}$ abordagem dessa trajetória histórica, dados importantes são resgatados em torno da constituição da clínica com crianças e do trabalho precursor realizado, na França, por Dolto e Mannoni. Além disso, encontramos nesse segundo eixo uma análise sobre a escolarização de pessoas com necessidades especiais em quatro países: Brasil, França, Itália e Estados Unidos, o que permite à autora indicar pontos de afinidade e de confrontação entre essas políticas educacionais, a partir da noção de laço social. No terceiro eixo, que se desdobra em três capítulos, a autora descreve e problematiza dados referentes a uma pesquisa de campo, desenvolvida durante um ano letivo em uma turma composta por crianças entre seis e sete anos de idade, que cursavam o primeiro ano do Ensino Fundamental em uma escola pública do município de Belo Horizonte (Minas Gerais). Dentre esses colegas, um componente do

520 Estilos clin., São Paulo, v. 19, n. 3, set./dez. 2014, 519-522. 
grupo apresentava comportamentos pouco usuais e uma linguagem bastante peculiar, diferenciando-se do que era comum aos colegas.

Por meio de sua imersão no cotidiano escolar desses sujeitos, da realização de entrevistas e filmagens, a autora sistematiza uma série de particularidades presentes na relação estabelecida entre essas crianças, o que lhe permite explorar os desdobramentos da noção de laço social, potencializada nas brincadeiras, cantorias e intervenções que perfazem o cotidiano escolar desse grupo. Nesse momento, conceitos como o de transitivismo e de objeto são convocados, possibilitando uma articulação mais pormenorizada dos dados extraídos do contato com os sujeitos à noção de laço social.

A forma minuciosa e teoricamente articulada como os pontos acima destacados são trabalhados no livro permite extrair duas contribuições desta produção para o debate da escolarização das pessoas ditas com deficiência nas últimas décadas e os desdobramentos da noção psicanalítica de laço social.

Uma primeira contribuição se materializa no fato do livro sistematizar um conjunto de ações das crianças - semelhantes, pequenos outros - no processo de inclusão escolar, ponto nem sempre enfatizado nos estudos sobre o tema. Nesse sentido, se a convivência na escola comum constitui-se em um princípio bastante difundido em publicações favoráveis à educação inclusiva por, supostamente, favorecer a construção de uma sociedade mais igualitária, a autora nos mostra que as crianças podem ocupar uma posição significativamente ativa na inserção escolar de colegas pouco convencionais quando o projeto pedagógico da escola aposta em uma construção pedagógica mais negociada em âmbito coletivo.

Uma segunda contribuição é a de demonstrar, a partir da discussão sobre a noção de laço social, que a proposta de uma educação inclusiva, difundida em vários países, contextualiza-se em um cenário marcado pela força do mercado, das relações de consumo e do individualismo. Tal constatação evidencia as contradições presentes na materialização dos princípios inclusivos, que contam, de um lado, com declarações internacionais, publicamente comprometidas com uma educação igualitária e para todos, e, de outro lado, com um sistema educativo cada vez mais marcado por uma sistemática avaliativa, que controla a prática docente e condiciona os investimentos na área. Nesse ponto, o diálogo com a proposição lacaniana dos discursos, em especial do discurso do capitalista, mostra-se essencial para qualificar esse paradoxo. 
O livro Laço social e educação possibilita, assim, um aprofundamento da discussão sobre os rumos da educação na contemporaneidade a partir de um referencial psicanalítico, abrindo tanto problematizações sobre os desafios que uma educação para todos impõe no cenário atual, quanto indicando a relevância de se escutar os sujeitos nesse processo, reconhecendo-os como atores que constroem o processo educativo ao lado dos profissionais da educação, funcionários e comunidade escolar.

dinizmargareth@yahoo.com.br Rua do Seminário, $\mathrm{S} / \mathrm{N}$ 35420-000 - Mariana - MG - Brasil.

Recebido em agosto/2014. Aceito em outubro/2014.

522 Estilos clin., São Paulo, v. 19, n. 3, set./dez. 2014, 519-522. 